\title{
Treatment outcome and compliance to dose-intensified linac-based SBRT for unfavorable prostate tumors using a novel real-time organ-motion tracking
}

\author{
Raffaella Lucchini ${ }^{1,2}$, Denis Panizza ${ }^{1,3}$, Riccardo Ray Colciago ${ }^{1,2^{*}}$ (D) , Veronica Vernier ${ }^{1}$, Martina Camilla Daniotti ${ }^{4}$,
} Valeria Faccenda ${ }^{3,5}$ and Stefano Arcangeli ${ }^{1,2}$

\begin{abstract}
Purpose/objectives: To report preliminary data on treatment outcome and compliance to dose-intensified organ sparing SBRT for prostate cancer using a novel electromagnetic transmitter-based tracking system (RayPilot ${ }^{\circledR}$ System) to account for intra-fractional organ motion.

Material/methods: Thirteen patients with intermediate unfavorable (9) and selected high-risk (4) prostate cancer underwent dose-escalated SBRT in 4 or 5 fractions $\left(\mathrm{BED}_{15}=279 \mathrm{~Gy}\right.$ and $253 \mathrm{~Gy}$, respectively). The VMAT treatment consisted in two 6FFF or 10FFF full arcs optimized to have the $95 \%$ isodose covering at least $95 \%$ of the PTV ( $2 \mathrm{~mm}$ isotropic expansion of the CTV). Whenever the real-time tracking registered a displacement that exceeded $2 \mathrm{~mm}$ during the setup and/or the beam delivery, the treatment was interrupted and the prostate motion was promptly corrected. The incidence of treatment-related genitourinary (GU) and gastrointestinal (GI) toxicity, patient QoL and PSA outcomes were computed from the start of treatment to the last follow-up date.
\end{abstract}

Results: All patients completed the treatment in the expected time (10.2 +/ -4.2 minutes) and their compliance to the procedure was excellent. No clinically significant acute Grade 2 or higher GI (rectal) and GU side effects were observed within 90 days from the treatment completion. The median IPSS increased from 8 at baseline to 12 onemonth after treatment and settled to 6 at 3 months. EPIC-26 scores in the urinary domain decreased from a median baseline of 86 pre-treatment to 79 at one-month and returned to baseline at a later timepoint (median score of 85 at 3 months). EPIC-26 scores in the bowel domains did not show significant changes within 3 months following RT. The prostate was found within $1 \mathrm{~mm}$ from its initial position in 78\% of the beam-on time, between 1 and $2 \mathrm{~mm}$ in 20\%, and exceeded $2 \mathrm{~mm}$ only in 2\%, after correction for motion which was performed in $45 \%$ of the fractions, either during setup or beam delivery.

Conclusions: Our preliminary findings show that dose intensified SBRT for unfavorable prostate tumors does not come at the cost of an increased toxicity, provided that a reliable technique for real time prostate monitoring is ensured. Fast FFF beams contributed to reduce intra-fractional motion. These observations need to be confirmed on a larger scale and a longer follow up.

*Correspondence: riccardoraycolciago@gmail.com

${ }^{1}$ Department of Radiation Oncology, School of Medicine and Surgery,

University of Milan Bicocca, Milan, Italy

Full list of author information is available at the end of the article

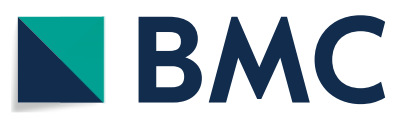

(c) The Author(s) 2021, , corrected publication 2021. Open Access This article is licensed under a Creative Commons Attribution 4.0 International License, which permits use, sharing, adaptation, distribution and reproduction in any medium or format, as long as you give appropriate credit to the original author(s) and the source, provide a link to the Creative Commons licence, and indicate if changes were made. The images or other third party material in this article are included in the article's Creative Commons licence, unless indicated otherwise in a credit line to the material. If material is not included in the article's Creative Commons licence and your intended use is not permitted by statutory regulation or exceeds the permitted use, you will need to obtain permission directly from the copyright holder. To view a copy of this licence, visit http://creativecommons.org/licenses/by/4.0/. The Creative Commons Public Domain Dedication waiver (http://creativecommons.org/publicdomain/zero/1.0/) applies to the data made available in this article, unless otherwise stated in a credit line to the data. 
Keywords: Prostate cancer, SBRT, Organ-motion tracking

\section{Background}

Conventional dose-escalated radiation therapy (RT) for organ-confined prostate cancer involves the delivery of a single 1.8-2.0 Gy fraction, five days per week, for eight-nine weeks to a total dose of 76-80 Gy. This regimen is based on four randomized trials and a metanalysis [1-5] showing improved progression-free free survival compared to lower cumulative doses, but at the cost of increased toxicity which prevents further dose escalation. Given this concomitant increase in toxicity with dose, as well as the expense and inconvenience of such a protracted course, alternative treatment schedules have been investigated. Clinical results from retrospective studies have led to the hypothesis that the $\alpha / \beta$ of prostate cancer is lower than that of the majority of human tumours, close to a value that is characteristic of late responding tissues [6-8]. Based on this assumption, the delivery of fewer and larger fractions (hypofractionation) than used in conventional RT, might effectively improve the therapeutic ratio while maintaining isoeffective tumour doses, and shortening overall treatment time.

This has inspired a number of clinical trials assessing the optimal dose per fraction when treating prostate cancer, and some of them have demonstrated the noninferiority of moderate hypofractionation (eg, 20 treatments) to conventional RT [9-12] in terms of efficacy and toxicity.

Along with tremendous advances in radiation technology that have enabled improved precision in the beam delivery, shorter radiation schedules than previously possible can now be implemented without compromising treatment efficacy, thus increasing patients' compliance and the cost-effectiveness profile of RT. Stereotactic body radiation therapy (SBRT) is characterized by the use of a high radiation dose per delivered fraction through highly intensity-modulated beams, generating sharper dose falloff and enhanced dose conformity to the target, which is ensured by strict adherence to the planned treatment via daily imaging. So far, most of the supporting evidence in favour of SBRT comes from two large systematic reviews $[13,14]$ and the results of one phase III study, HYPORT-PC [15]. Indeed, an American Society for Radiation Oncology/American Society of Clinical Oncology/ American Urological Association (ASTRO/ASCO/AUA) guideline included recommendations regarding the use of ultrahypofractionation (eg, SBRT) in the treatment of low-intermediate risk prostate cancer [16]. Evidence has accumulated that SBRT for patients with low and intermediate risk prostate cancer is associated with excellent biochemical outcomes and acceptably low toxicity rates [17]. However, caution is advised when dose-escalated SBRT aimed at maximizing tumor control for more aggressive disease is needed, in view of the non-negligible risk of high grade toxicity [18]. The aim of the present study is to report preliminary data on treatment outcome and compliance to dose-intensified organ-sparing SBRT for intermediate and selected high-risk prostate cancer using a novel electromagnetic transmitter-based tracking system to account for intra-fractional organ motion.

\section{Methods}

\section{Patients}

Patients over the age 50 with histologically confirmed organ-confined prostate adenocarcinoma considered at intermediate unfavorable and selected high risk (eg. Gleason Grade Group V, cT3b disease and prostate specific antigen (PSA) $>20 \mathrm{ng} / \mathrm{mL}$ excluded) as per National Comprehensive Cancer Network definition, with an international prostate symptoms score (IPSS) $\leq 19$ (alpha-blockers allowed) and a compute tomography (CT), magnetic resonance imaging (MRI) or Ultrasoundbased volume estimation of prostate gland $\leq 100$ g were included. All patients, but 4 (who refused any form of endocrine manipulation), received concomitant androgen deprivation therapy (ADT) as per standard of care [19]. Institutional review board approval was obtained, and all participants provided written consent.

\section{Treatment planning and radiation delivery}

Patients were immobilized in supine position using FeetFix $^{\circledR}$ (CIVCO Medical Solutions, Iowa, US) system anchored to the couch for ankle fixation, with arms placed over their chest. A micro-enema was administered before simulation and each treatment to assess anatomical reproducibility. A monitoring system (RayPilot ${ }^{\circledR}$ System by Micropos Medical AB, Gothenburg, Sweden) provided real-time localization of the prostate based on electro-magnetic detection of a transmitter, which was placed intra-urethrally by means of a dedicated catheter to identify anatomy and allow intra-fractional tracking (Fig. 1). The same catheter was used to fill the bladder with $100 \mathrm{cc}$ of saline solution.

A T2W MRI was acquired in treatment position and fused with the simulation CT to accurately delineate the target volume and the organs-at-risk. The clinical target volume (CTV) was the prostate and the seminal vesicles. The planning target volume (PTV) included CTV with a $2 \mathrm{~mm}$ isotropic 3D-margin. A margin of $2 \mathrm{~mm}$ 


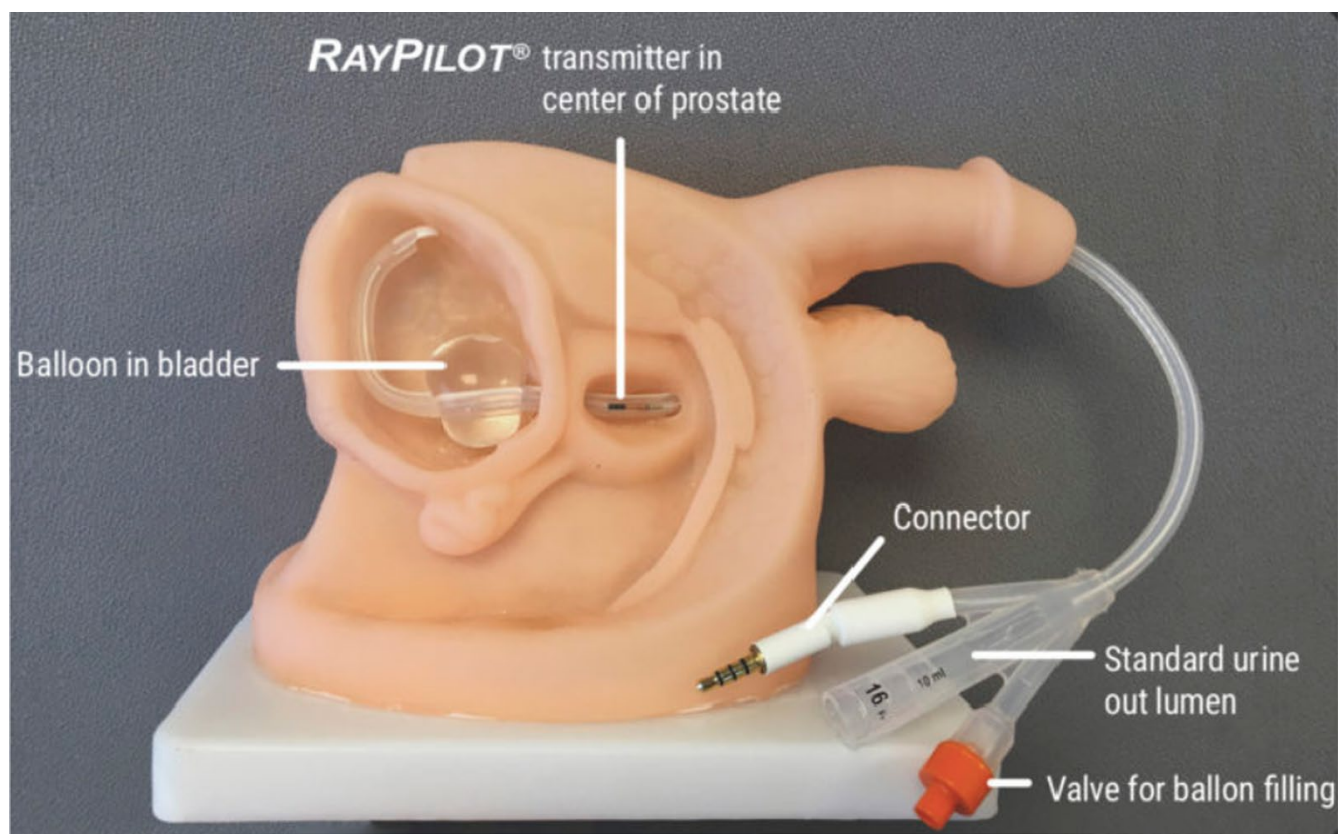

Fig. 1 RayPilot ${ }^{\circledR}$ main components

was applied around the catheter to determine a planning organ at risk volume (PRV) for the urethra in order to provide a significant dose-sparing at this level, allowing a negative dose-painting to reduce the risk of treatment-related urinary toxicity. A Volumetric Modulated Arc Therapy treatment consisted in two $6 \mathrm{MV}$ or $10 \mathrm{MV}$ flattening filter free (FFF) full arcs optimized to have the $95 \%$ isodose covering at least $95 \%$ of the PTV. SBRT was scheduled every day for a total dose either of $40 \mathrm{~Gy}$ in 5 fractions or 38 Gy in 4 fractions. The corresponding
Biologically Effective Dose considering an $\alpha / \beta$ ratio of 1.5 Gy was 253 Gy and 279 Gy, respectively.

Mandatory dose-volume constraints were defined for both target coverage and avoidance of normal adjacent tissues, including rectum, rectum wall, bladder, PRV of urethra and penile bulb, as shown in Table 1. Accurate patient setup was obtained by ConeBeam-CT (CBCT) before treatment, and real-time motion tracking ensured that both the setup and the beam delivery phases were interrupted and corrected whenever the displacement exceeded a predetermined $2 \mathrm{~mm}$ threshold. In case of

Table 1 Planning objectives for dose-escalated prostate SBRT

\begin{tabular}{|c|c|c|c|c|}
\hline & Dose objective & Expected (4 fractions) & Expected (5 fractions) & Priority \\
\hline \multirow[t]{5}{*}{ Rectum } & Dmax (0.035 cc) & 38 Gy (100\% prescribed dose) & 42 Gy (105\% prescribed dose) & 1 \\
\hline & D5\% & $\leq 33 \mathrm{~Gy}$ & $\leq 40 \mathrm{~Gy}$ & 2 \\
\hline & D10\% & $\leq 29 \mathrm{~Gy}$ & $\leq 36 \mathrm{~Gy}$ & 2 \\
\hline & D20\% & $\leq 26.5 \mathrm{~Gy}$ & $\leq 32 \mathrm{~Gy}$ & 2 \\
\hline & D50\% & $\leq 16.7 \mathrm{~Gy}$ & $\leq 20 \mathrm{~Gy}$ & 2 \\
\hline Rectal mucosa & Dmax (0.035 cc) & 28.5 (75\% prescribed dose) & - & 1 \\
\hline \multirow[t]{3}{*}{ Bladder } & Dmax (0.035 cc) & 45.6 Gy (120\% prescribed dose) & 44 Gy (110\% prescribed dose) & 1 \\
\hline & D10\% & $\leq 41.8$ Gy (110\% prescribed dose) & $\leq 38$ Gy (95\% prescribed dose) & 1 \\
\hline & D40\% & $\leq 16.6 \mathrm{~Gy}$ & $\leq 20 \mathrm{~Gy}$ & 2 \\
\hline \multirow[t]{2}{*}{ PRV Urethra } & Dmax (0.035 cc) & 45.6 Gy (120\% prescribed dose) & 48 Gy (120\% prescribed dose) & 1 \\
\hline & D10\% & $\leq 41.8$ Gy (110\% prescribed dose) & $\leq 44$ Gy (110\% prescribed dose) & 1 \\
\hline Penile bulb & Dmax (0.035 cc) & 38 Gy (100\% prescribed dose) & 40 Gy (100\% prescribed dose) & 3 \\
\hline
\end{tabular}


prolonged drift outside this tolerance, a new CBCT was prompted and matched to correct for prostate motion.

\section{Toxicity and quality of life assessment}

Toxicity, as defined by National Cancer Institute Common Terminology Criteria for Adverse Events v.5.0, was assessed during treatment, at one-month and at 3 months. IPSS [20] and Expanded Prostate Cancer Index Composite Short Form (EPIC-26) bowel and urinary Quality of Life (QoL) [21] scores were collected once prior to treatment and then following treatment at the above time points via questionnaries. The incidence of acute treatment related genitourinary (GU) and gastrointestinal (GI) toxicity, patient QoL and PSA outcomes were computed from the start of treatment to the last follow-up date.

\section{Results}

\section{Patient characteristics}

From June 2020 to May 2021, 13 patients were included. Median age was 77 years (range 63-81). Intermediate unfavorable and high-risk prostate cancer accounted for $69 \%$ and $31 \%$ respectively. Median PSA at baseline was $9.78 \mathrm{ng} / \mathrm{mL}$ (range 4.99-20). Median CTV and PTV were $47.05 \mathrm{cc}$ (range 32.06-96.71) and $66.6 \mathrm{cc}$ (range 48.89-128.53), respectively. Patients, tumors and treatment characteristics are summarized in Table 2.

\section{Organ motion mitigation}

In 56 treated fractions, $86 \mathrm{CBCT}$ to planning $\mathrm{CT}$ matchings were performed. In 31/56 fractions (55\%), the signal was within the $2 \mathrm{~mm}$ threshold for the whole time. Interruption triggered by the tracking system occurred in $25 / 56$ (45\%) of the monitored fractions and a new CBCT was mandated. Specifically, in 15 fractions (27\%), at least one $\mathrm{CBCT}$ was repeated during the initial setup phase before starting the beam delivery. In 10 fractions (18\%), the treatment was interrupted and the patients were repositioned. Mean delivery time (beam-on time \pm interruptions) was $3.5 \pm 0.9 \mathrm{~min}$ (2.5-7.3), mean time to treatment from patient setup to beam-off was $10.2 \pm 4.2 \mathrm{~min}$ with a median time of $8 \mathrm{~min}(5.5-22.7)$. The mean value of the target average deviation was $-0.18 \mathrm{~mm}, 0.01 \mathrm{~mm}$, and $-0.26 \mathrm{~mm}$ in lateral, longitudinal, and vertical direction, respectively, indicating a negligible systematic component (Table 3). All data points from the 56 analyzed fractions were used to evaluate the percentage of time that the transmitter (and thus the prostate) was offset from its reference position. For the purposes of histogram analysis, displacement from the reference position was divided into $1-\mathrm{mm}$ increments. The prostate was found within $1 \mathrm{~mm}$ from its initial position in $78 \%$ of the delivery time, between 1 and $2 \mathrm{~mm}$ in $20 \%$, and exceeded
Table 2 Baseline patients, tumors and treatment characteristics

\begin{tabular}{|c|c|c|}
\hline \multicolumn{3}{|l|}{ Age } \\
\hline Median & 77 & Range [63-81] \\
\hline \multicolumn{3}{|l|}{ Comorbidities } \\
\hline None & $4(30.7 \%)$ & \\
\hline 1 Comorbidity & $4(30.7 \%)$ & \\
\hline$>1$ Comorbidities & $5(38.6 \%)$ & \\
\hline \multicolumn{3}{|l|}{ Anticoagulants } \\
\hline Yes & $5(38.6 \%)$ & \\
\hline No & $8(61.4 \%)$ & \\
\hline \multicolumn{3}{|l|}{ Alpha blockers } \\
\hline Yes & $5(38.6 \%)$ & \\
\hline No & $8(61.4 \%)$ & \\
\hline \multicolumn{3}{|l|}{ IPSS } \\
\hline Median & 8 & Range [2-14] \\
\hline \multicolumn{3}{|l|}{ Prostate volume (mL) } \\
\hline Median & 35.5 & Range [24-80] \\
\hline \multicolumn{3}{|l|}{ NCCN risk group } \\
\hline Intermediate unfavorable & $7(69.2 \%)$ & \\
\hline High & $3(23.1 \%)$ & \\
\hline Very High & $1(7.7 \%)$ & \\
\hline \multicolumn{3}{|l|}{ Gleason score } \\
\hline $7(4+3)$ & $9(69.2 \%)$ & \\
\hline $8(4+4)$ & $2(15.4 \%)$ & \\
\hline $9(4+5)$ & $1(7.7 \%)$ & \\
\hline $10(5+5)$ & $1(7.7 \%)$ & \\
\hline \multicolumn{3}{|l|}{ ISUP grading group } \\
\hline 3 & $9(69.2 \%)$ & \\
\hline 4 & $2(15.4 \%)$ & \\
\hline 5 & $2(15.4 \%)$ & \\
\hline \multicolumn{3}{|l|}{ Clinical stage } \\
\hline T2a & $4(30.8 \%)$ & \\
\hline $\mathrm{T} 2 \mathrm{~b}$ & $2(15.4 \%)$ & \\
\hline $\mathrm{T} 2 \mathrm{C}$ & $6(46.1 \%)$ & \\
\hline ТЗа & $1(7.7 \%)$ & \\
\hline \multicolumn{3}{|l|}{ PSA level (mg/mL) } \\
\hline Median & 9.78 & Range [4.99-20] \\
\hline$<10$ & $8(61.4 \%)$ & \\
\hline $10-20$ & $5(38.6 \%)$ & \\
\hline \multicolumn{3}{|c|}{ Radiation therapy prescribed and delivered } \\
\hline 40 Gy in 5 fractions & $4(30.8 \%)$ & \\
\hline 38 Gy in 4 fractions & $9(69.2 \%)$ & \\
\hline \multicolumn{3}{|l|}{ CTV (cc) } \\
\hline Median & 47.05 & Range [32.06-96.71] \\
\hline \multicolumn{3}{|l|}{ PTV (cc) } \\
\hline Median & 66.60 & Range [48.89-128.53] \\
\hline \multicolumn{3}{|l|}{ PTV (D95) } \\
\hline Median & $96 \%$ & Range [95-97\%] \\
\hline
\end{tabular}


Table 3 Summary of trajectory evaluation from intrafractional prostate monitoring: mean, standard deviation and maximum displacement values

\begin{tabular}{|c|c|c|c|c|}
\hline \multirow[t]{2}{*}{ Treatment phase } & \multirow[t]{2}{*}{ Displacement (mm) } & \multicolumn{3}{|l|}{ Directions } \\
\hline & & Lateral & Longitudinal & Vertical \\
\hline \multirow[t]{2}{*}{ Setup } & Mean & $-0.20 \pm 0.45$ & $-0.07 \pm 0.74$ & $-0.21 \pm 0.81$ \\
\hline & Maximum & 4.88 & 7.75 & 17.73 \\
\hline \multirow[t]{2}{*}{ Dose delivery } & Mean & $-0.14 \pm 0.41$ & $0.15 \pm 0.70$ & $-0.33 \pm 0.73$ \\
\hline & Maximum & 3.09 & 5.23 & 12.74 \\
\hline \multirow[t]{2}{*}{ Global treatment } & Mean & $-0.18 \pm 0.46$ & $0.01 \pm 0.77$ & $-0.26 \pm 0.82$ \\
\hline & Maximum & 4.88 & 6.20 & 17.73 \\
\hline
\end{tabular}

Table 4 Rates of 30 days and 90 days side effects from the start of treatment

\begin{tabular}{llllll}
\hline Genitourinary toxicity & & & \multicolumn{2}{c}{ Gastrointestinal toxicity } \\
\cline { 1 - 2 } & $\mathbf{3 0}$ days & $\mathbf{9 0}$ days & & $\mathbf{3 0 \text { days }}$ & $\mathbf{9 0}$ days \\
\hline Grade & & & & $1(7.7 \%)$ & $2(15.4 \%)$ \\
1 & $5(38.6 \%)$ & $5(38.6 \%)$ & & $0(0)$ & $0(0)$ \\
2 & $0(0)$ & $0(0)$ & & $0(0)$ & $0(0)$ \\
\hline 3 & $0(0)$ & $0(0)$ & &
\end{tabular}

$2 \mathrm{~mm}$ only in $2 \%$. When considering the overall treatment time (setup time + beam-on time + interruptions), the same features were $83 \%$ (within $1 \mathrm{~mm}$ ), $13 \%$ (between 1 and $2 \mathrm{~mm}$ ), and $4 \%$ (in excess of $2 \mathrm{~mm}$ ), respectively.

\section{Treatment outcome}

All patients completed the treatment in the expected time and their compliance to the procedure was excellent. No clinically significant acute Grade 2 or higher GI (rectal) and GU side effects were observed within 90 days from the treatment completion. At 30-days, only one (7.7\%) patient experienced acute Grade 1 GI toxicity (proctitis), while acute Grade $1 \mathrm{GU}$ toxicity (dysuria) occurred in five (38.6\%) patients. At 90-days, Grade 1 GI and Grade $1 \mathrm{GU}$ toxicity occurred in two (15.4\%) and five $(38.6 \%)$ patients, respectively (Table 4$)$. At 3 months, a PSA assessment showed a median value of $1.85 \mathrm{ng} / \mathrm{mL}$ (range $0.01-3.86 \mathrm{ng} / \mathrm{mL}$ ).

\section{Quality of life}

The median IPSS increased from 8 at baseline to 12 onemonth after treatment, and settled at 6 at 3 months, approximating the pre-treatment baseline value. Consistent with the results of the IPSS, EPIC-26 scores in the urinary domain decreased from a median baseline of 86 pre-treatment to 79 at one-month and returned to baseline at a later timepoint (median score of 85 at 3 months).
There was no significant decrease in the 3 months median EPIC-26 scores in the bowel domains. (Fig. 2).

\section{Discussion}

Mounting evidence show favorable outcomes for lowand intermediate-risk prostate cancer patients treated with SBRT with short- and medium-term follow-up [22-41], and the ASTRO/ASCO/AUA guideline has recently issued a shared guideline lending support to the use of SBRT for prostate cancer, which has matured to a point where it can be considered an appropriate alternative to both conventional and moderately hypofractionated RT [16]. The most popular schedule is $35-36.25$ Gy in five fractions, which carried excellent results, with a 5-year biochemical-Disease Free Survival (b-DFS) ranging from 94 to $97 \%$ in low-risk patients, but appears to be suboptimal in intermediate risk patients, who experienced a 5 -year b-DFS of only $84 \%$, as showed in a pooled analysis of eight institutions [42]. The attempt to further escalated the dose, however, was associated with unacceptable toxicity: in a dose-escalation trial [18], 6.6\% of patients treated at the highest dose level $(50 \mathrm{~Gy}$ in five fractions) developed high grade rectal toxicity, 5 of whom required colostomy. In addition, the odds of having a late grade $2+\mathrm{GU}$ toxicity were 18 -fold higher for patients treated with SBRT schedules of 40 Gy compared to those treated with $35 \mathrm{~Gy}$ [36]. Not even the use of proton seems to hold sufficient promises for SBRT dose intensification, in view of the disappointing results of two normo-fractionated trials, showing a $50 \%$ greater incidence of rectal toxicity compared to IMRT [43], and a significant (8\%) late grade 3 rectal toxicity when proton dose was escalated to 82 Gy [44], respectively. Additionally, since only preliminary data of a randomized phase II trial comparing different SBRT schedules for favorable risk prostate cancer have been published [45], the optimal dose for prostate SBRT is yet to be defined [46]. In this report of dose-intensified organ-sparing SBRT for unfavorable risk prostate cancer, low rates of 

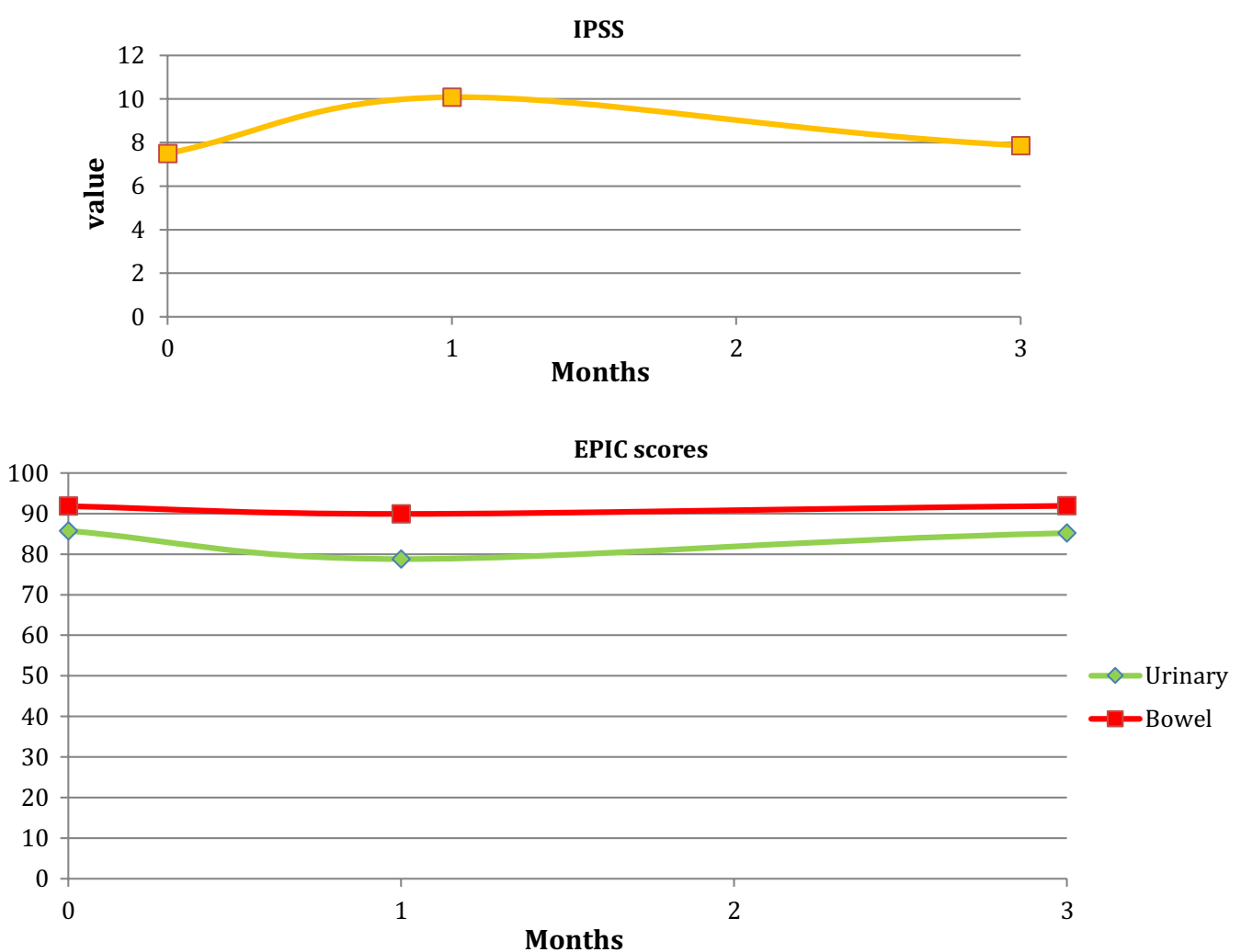

Fig. 2 Time course of IPSS and EPIC-26 scores for bowel and urinary domains

genitourinary and gastrointestinal toxicity were observed with little change in QoL by IPSS and EPIC-26 scores. Despite the high dose employed in this series, the early toxicity outcomes are in keeping with the large majority of SBRT trials, where lower doses have been used, and definitely better when compared with dose-escalated regimens (Table 5). The low-toxicity profile in this study may be attributed to the strict adherence to planning criteria and the application of tight margins around the CTV, as well as the restrictive selection criteria, including the selection of patients with prostate volume $\leq 100 \mathrm{~g}$ and IPSS scores $<19$. While without continuous monitoring and intervention, in approximately $10 \%$ of patients intrafractional motion would lead to target missing [47], the use of a novel electromagnetic transmitter-based tracking system afforded sub-millimeter precision in tumor targeting during treatment delivery, enabling the reduction of safety margins up to $2 \mathrm{~mm}$. Furthermore, the location of the urethra was clearly identified on the fused CT/ MRI set by virtue of the catheter. With a $2 \mathrm{~mm}$ expansion around the catheter, negative dose-painting around the urethra significantly contributed to reduce the risk of GU toxicity. Ultimately, the very high dose rates available with the use of FFF beams allowed a significant reduction of total session treatment time, thus decreasing the risk of intra-fraction motion, which might have resulted in less toxicity and accordingly in a better QoL. Similar to the mild toxicity in this study, follow-up extending out to 6 months post-treatment showed limited to no change in QoL as measured by either IPSS, or EPIC-26 scores in both the urinary and bowel domains. Mean EPIC urinary and bowel QoL declined at one-month post-treatment, but almost settled to baseline by 3 months. Our findings should be interpreted with caution given the low rate of events and the short follow-up that cannot capture long-term adverse effects, nor meaningful differences in treatment outcomes compared to similar SBRT regimens. Likewise, the ability to draw any conclusion on the efficacy of high-dose SBRT is scarce. However, as the rate and magnitude of PSA decline following definitive RT for prostate cancer seem to be correlated with clinical outcomes [48-50], the median value of PSA nadir at 3 months in our series indicates an optimal treatment response at least at a very early timepoint. Nevertheless, our study shows that, unlike dose-escalation experiences either with standard fractionated External Beam RT [1-4], protontherapy [44] or SBRT [18] for prostate cancer, the worthy cost-effectiveness profile of our approach 
Table 5 Previously published rates of toxicity following prostate SBRT

\begin{tabular}{|c|c|c|c|c|c|c|c|}
\hline \multirow[t]{2}{*}{ Study } & \multirow[t]{2}{*}{$\mathrm{n}$} & \multirow[t]{2}{*}{ Dose/fractions } & \multirow[t]{2}{*}{ Scale } & \multicolumn{2}{|c|}{ Genitourinary toxicity } & \multicolumn{2}{|c|}{ Gastrointestinal toxicity } \\
\hline & & & & Grade 2 & $\geq$ Grade 3 & Grade 2 & $\geq$ Grade 3 \\
\hline Kim [16] & 91 & $45-50 / 5$ & CTCAE v.3 & $\begin{array}{l}\text { Acute } 22 \% \\
\text { Late } 20.9 \%\end{array}$ & $\begin{array}{l}\text { Acute } 0 \% \\
\text { Late } 5.5 \%\end{array}$ & $\begin{array}{l}\text { Acute } 20.9 \% \\
\text { Late } 13.2 \%\end{array}$ & $\begin{array}{l}\text { Acute } 2.2 \% \\
\text { Late } 6.6 \%\end{array}$ \\
\hline Madsen [21] & 40 & $33.5 / 5$ & CTCAE v.2 & $\begin{array}{l}\text { Acute } 20.5 \% \\
\text { Late } 20 \%\end{array}$ & $\begin{array}{l}\text { Acute } 2.5 \% \\
\text { Late } 0 \%\end{array}$ & $\begin{array}{l}\text { Acute } 13 \% \\
\text { Late } 7.5 \%\end{array}$ & $\begin{array}{l}\text { Acute } 0 \% \\
\text { Late } \%\end{array}$ \\
\hline Tang [22] & 30 & $35 / 5$ & & Acute 13\% & Acute 0\% & Acute 7\% & Acute $0 \%$ \\
\hline McBride [23] & 34 & $37.5-36.25 / 5$ & CTCAE v.4 & $\begin{array}{l}\text { Acute 19\% } \\
\text { Late 17\% }\end{array}$ & $\begin{array}{l}\text { Acute } 0 \% \\
\text { Late } 2 \%\end{array}$ & $\begin{array}{l}\text { Acute } 7 \% \\
\text { Late } 7 \%\end{array}$ & $\begin{array}{l}\text { Acute } 0 \% \\
\text { Late } 5 \%\end{array}$ \\
\hline Alongi [24] & 40 & $35 / 5$ & CTCAE v.4 & $\begin{array}{l}\text { Acute } 40 \% \\
\text { Late } 2.5 \%\end{array}$ & $\begin{array}{l}\text { Acute } 0 \% \\
\text { Late } 0 \%\end{array}$ & $\begin{array}{l}\text { Acute } 10 \% \\
\text { Late } 0 \%\end{array}$ & $\begin{array}{l}\text { Acute } 0 \% \\
\text { Late 0\% }\end{array}$ \\
\hline Boyer [25] & 60 & $37 / 5$ & CTCAE v.4 & Late 6.7\% & Late 0\% & Late 8.3\% & Late 1.7\% \\
\hline King $[26]$ & 67 & $36.25 / 5$ & RTOG & Late $5 \%$ & Late $3.5 \%$ & Late $2 \%$ & Late 0\% \\
\hline Bolzicco [27] & 100 & $35 / 5$ & RTOG & $\begin{array}{l}\text { Late } 3 \% \\
\text { Acute } 12 \%\end{array}$ & $\begin{array}{l}\text { Late } 1 \% \\
\text { Acute } 0 \%\end{array}$ & $\begin{array}{l}\text { Late } 1 \% \\
\text { Acute } 18 \%\end{array}$ & Late 0\% \\
\hline Elias [28] & 84 & $35 / 5$ & RTOG & $\begin{array}{l}\text { Late } 5.9 \% \\
\text { Acute } 20.2 \%\end{array}$ & Late 0\% & $\begin{array}{l}\text { Late } 7.1 \% \\
\text { Acute } 9.5 \%\end{array}$ & Late 1.1\% \\
\hline Katz [29] & 515 & $35-36.25 / 5$ & RTOG & $\begin{array}{l}\text { Late } 9.1 \% \\
\text { Acute } 4 \%\end{array}$ & $\begin{array}{l}\text { Late } 1.7 \% \\
\text { Acute } 0 \%\end{array}$ & $\begin{array}{l}\text { Late } 4 \% \\
\text { Acute 4\% }\end{array}$ & $\begin{array}{l}\text { Late } 4 \% \\
\text { Acute } 0 \%\end{array}$ \\
\hline Bernetich [30] & 142 & $35-36.25-37.5 / 5$ & CTCAE v.3 & $\begin{array}{l}\text { Late } 14 \% \\
\text { Acute } 28 \%\end{array}$ & $\begin{array}{l}\text { Late } 2 \% \\
\text { Acute } 2 \%\end{array}$ & $\begin{array}{l}\text { Late } 3 \% \\
\text { Acute } 4 \%\end{array}$ & $\begin{array}{l}\text { Late } 0 \% \\
\text { Acute } 0 \%\end{array}$ \\
\hline Gurka [31] & 208 & $35-36.25 / 5$ & CTCAE v.4 & $\begin{array}{l}\text { Late } 2.4 \% \\
\text { Acute } 0.9 \%\end{array}$ & $\begin{array}{l}\text { Late } 1.4 \% \\
\text { Acute } 0 \%\end{array}$ & N.A & N.A \\
\hline Seymour [32] & 56 & $38 / 4$ & CTCAE v.4 & $\begin{array}{l}\text { Late } 19.6 \% \\
\text { Acute } 35.7 \%\end{array}$ & $\begin{array}{l}\text { Late } 3.6 \% \\
\text { Acute } 0 \%\end{array}$ & N.A & N.A \\
\hline Qi [33] & 86 & $40 / 5$ & EPIC QOL & $\begin{array}{l}\text { Obs/irrit MID: } 46 \% \\
\text { Incont MID: } 28 \%\end{array}$ & N.A & N.A & N.A \\
\hline Kole [34] & 216 & $35-36.25 / 5$ & IPSS & Late $13 \%$ & N.A & N.A & N.A \\
\hline Helou [35] & 259 & $35-40 / 5$ & RTOG & Late $32.6 \%$ & Late 1.9\% & Late $12.9 \%$ & Late 1.1\% \\
\hline Zhang [36] & 78 & $38 / 4$ & CTCAE v.4 & Late 19.2\% & Late $2.6 \%$ & & \\
\hline Jackson [37] & 66 & $37 / 5$ & CTCAE v.4 & $\begin{array}{l}\text { Late } 1.9 \% \\
\text { Acute } 23 \%\end{array}$ & $\begin{array}{l}\text { Late } 0 \% \\
\text { Acute } 0 \%\end{array}$ & $\begin{array}{l}\text { Late } 5 \% \\
\text { Acute } 4 \%\end{array}$ & $\begin{array}{l}\text { Late } 0 \% \\
\text { Acute } 0 \%\end{array}$ \\
\hline Musunuru [38] & 258 & $35-40 / 5$ & CTCAE v.3 & N.A & N.A & Late $16.2 \%$ & Late $3.2 \%$ \\
\hline Miszczyk [39] & 400 & $36.25 / 5$ & RTOG & $\begin{array}{l}\text { Late } 2.9 \% \\
\text { Acute } 4 \%\end{array}$ & $\begin{array}{l}\text { Late } 0 \% \\
\text { Acute } 0.4 \%\end{array}$ & $\begin{array}{l}\text { Late } 0.6 \% \\
\text { Acute } 1.6 \%\end{array}$ & $\begin{array}{l}\text { Late } 0.3 \% \\
\text { Acute } 0.4 \%\end{array}$ \\
\hline Zelefsky [40] & 551 & $35-40 / 5$ & & $\begin{array}{l}\text { Late } 21.1 \% \\
\text { Acute } 10 \%\end{array}$ & $\begin{array}{l}\text { Late } 2.5 \% \\
\text { Acute } 0.7 \%\end{array}$ & $\begin{array}{l}\text { Late } 3.4 \% \\
\text { Acute } 1.8 \%\end{array}$ & $\begin{array}{l}\text { Late } 0.4 \% \\
\text { Acute } 0 \%\end{array}$ \\
\hline Current series & 15 & $\begin{array}{l}38 / 4 \\
40 / 5\end{array}$ & CTCAE v. 5 & $\begin{array}{l}\text { Acute 0\% } \\
\text { Late 0\% }\end{array}$ & $\begin{array}{l}\text { Acute 0\% } \\
\text { Late 0\% }\end{array}$ & $\begin{array}{l}\text { Acute } 0 \% \\
\text { Late } 0 \%\end{array}$ & $\begin{array}{l}\text { Acute } 0 \% \\
\text { Late } 0 \%\end{array}$ \\
\hline
\end{tabular}

does not necessarily come at the cost of an increased toxicity, provided that a close attention is paid to ensure pelvic anatomy reproducibility and target stability during treatment. While the results of this study are hypothesis generating, their validation on a larger scale is needed to implement strategies for safe dose escalation in the SBRT setting based on novel techniques that can reduce intrafractional prostate motion.

\section{Abbreviations}

RT: Radiation therapy; SBRT: Stereotactic body radiation therapy; ASTRO: American Society for Radiation Oncology; ASCO: American Society of Clinical Oncology; AUA: American Urological Association; PSA: Prostatic specific antigen; IPSS: International prostatic symptoms score; CT: Computed tomography;
ADT: Androgen deprivation therapy; MRI: Magnetic resonance image; FFF: Flattening filter free; PTV: Planning target volume; CTV: Clinical target volume; PRV: Planning organ at risk volume; GU: GenitoUrinary; $C B C T$ : Cone beam computed tomography; EPIC: Expanded prostate cancer index composite short form; QoL: Quality of life; Gl: Gastrolntestinal; b-DFS: Biochemical-Disease free survival.

\section{Acknowledgements}

Not applicable.

\section{Authors' contributions}

SA conceived the study; RL and DP analyzed and interpreted data; SA, RL and DP wrote the manuscript; RL, RRC, W, MCD, VF: collected data; All the authors approved the final version of the manuscript.

\section{Funding}

Not applicable. 


\section{Availability of data and materials}

The datasets supporting the conclusions of this article are included within the article.

\section{Declarations}

Ethics approval and consent to participate

Not applicable.

\section{Consent for publication}

Not applicable.

\section{Competing interests}

The authors declare that they have no competing interests.

\section{Author details}

'Department of Radiation Oncology, School of Medicine and Surgery, University of Milan Bicocca, Milan, Italy. ${ }^{2}$ Radiation Oncology Department, ASST Monza, Monza, Italy. ${ }^{3}$ Medical Physics Department, ASST Monza, Monza, Italy. ${ }^{4}$ Department of Physics, University of Milan Bicocca, Milan, Italy. ${ }^{5}$ Department of Physics, University of Milan, Milan, Italy.

Received: 13 August 2021 Accepted: 7 September 2021

Published online: 17 September 2021

\section{References}

1. Dearnaley DP, Jovic G, Syndikus I, et al. Escalated-dose versus controldose conformal radiotherapy for prostate cancer: long-term results from the MRC RT01 randomised controlled trial. Lancet Oncol. 2014;15:464-73.

2. Kuban DA, Tucker SL, Dong L, et al. Long-term results of the M. D. Anderson randomized dose-escalation trial for prostate cancer. Int J Radiat Oncol Biol Phys. 2008;70:67-74.

3. Al-Mamgani A, van Putten WLJ, Heemsbergen WD, et al. Update of Dutch multicenter dose-escalation trial of radiotherapy for localized prostate cancer. Int J Radiat Oncol Biol Phys. 2008;72(4):980-8.

4. Zietman AL, Bae K, Slater JD, et al. Randomized trial comparing conventional-dose with high-dose conformal radiation therapy in early-stage adenocarcinoma of the prostate: long-term results from proton radiation oncology group/american college of radiology 95-09. J Clin Oncol. 2010;28:1106-11.

5. Viani GA, Stefano EJ, Afonso SL. Higher-than-conventional radiation doses in localized prostate cancer treatment: a meta-analysis of randomized controlled trials. Int J Radiat Oncol Biol Phys. 2009;74(5):1405-18.

6. Proust-Lima $C$, et al. Confirmation of a low $a / \beta$ ratio for prostate cancer treated by external beam radiation therapy alone using a post-treatment repeated measuresmodel for PSA dynamics. Int J Radiat Oncol Biol Phys. 2011;79:195-201.

7. Miralbell R, Roberts SA, Zubizarreta E, Hendry JH. Dose-fractionation sensitivity of prostate cancer deduced from radiotherapy outcomes of 5969 patients in seven international institutional datasets: $\alpha / \beta=1.4(0.9-2.2)$ Gy. Int J Radiat Oncol Biol Phys. 2012:82:e17-24.

8. Dasu A, Toma-Dasu I. Prostate $\alpha / \beta$ revisited —an analysis of clinical results from 14168 patients. Acta Oncol. 2012:51:963-74.

9. Hoffman KE, Voong KR, Levy LB, et al. Randomized trial of hypofractionated dose-escalated intensity modulated radiation therapy versus conventionally fractionated intensity modulated radiation therapy for localized prostate cancer. Int J Radiat Oncol Biol Phys. 2016;96:S32.

10. Dearnaley D, Syndikus I, Mossop H, et al. Conventional versus hypofractionated high-dose intensity-modulated radiotherapy for prostate cancer: 5-year outcomes of the randomised, non-inferiority, phase $3 \mathrm{CHHiP}$ trial. Lancet Oncol. 2016;17:1047-60.

11. Catton CN, Lukka H, Gu CS, et al. Randomized trial of a hypofractionated radiation regimen for the treatment of localized prostate cancer. J Clin Oncol. 2017:35:1884-90.

12. Lee WR, Dignam JJ, Amin MB, et al. Randomized phase III noninferiority study comparing two radiotherapy fractionation schedules in patients with low-risk prostate cancer. J Clin Oncol. 2016;34(2325-2332):5.
13. Kishan AU, Dang A, Katz AJ, et al. Long-term outcomes of stereotactic body radiotherapy for low-risk and intermediate-risk prostate cancer. JAMA Netw Open. 2019:2:e188006.

14. Jackson WC, Silva J, Hartman HE, et al. Stereotactic body radiation therapy for localized prostate cancer: a systematic review and meta-analysis of over 6000 patients treated on prospective studies. Int J Radiat Oncol Biol Phys. 2019;104:778-89.

15. Widmark A, Gunnlaugsson A, Beckman L, et al. Ultra-hypofractionated versus conventionally fractionated radiotherapy for prostate cancer: 5-year outcomes of the HYPO-RT-PC randomised, non-inferiority, phase 3 trial. Lancet. 2019;394:385-95.

16. Morgan SC, Hoffman K, Loblaw DA, et al. Hypofractionated radiation therapy for localized prostate cancer: an ASTRO, ASCO, and AUA evidence-based guideline. J Clin Oncol. 2018;8:354-60.

17. Wang K, Mavroidis P, Royce TJ, et al. Prostate stereotactic body radiation therapy: an overview of toxicity and dose response. Int J Radiat Oncol Biol Phys. 2021;110(1):237-48

18. Kim NDW, Cho LC, Straka C, et al. Predictors of rectal tolerance observed in a dose-escalated phase 1-2 trial of stereotactic body radiation therapy for prostate cancer. Int J Radiat Oncol Biol Phys. 2014;89:509-17.

19. Schaeffer E, Srinivas S, Antonarakis ES, et al. Prostate cancer, version 1.2021 featured updates to the NCCN guidelines. J Natl Compr Canc Netw. 2021;19(2):134-43

20. Barry MJ, Fowler FJ Jr, O'Leary MP, et al. The American Urological Association symptom index for benign prostatic hyperplasia. The Measurement Committee of the American Urological Association. J Urol. 1992:148:1549-57.

21. Wei JT, Dunn RL, Litwin MS, et al. Development and validation of the expanded prostate cancer index composite (EPIC) for comprehensive assessment of health-related quality of life in men with prostate cancer Urology. 2000:56:899-905.

22. Madsen $\mathrm{BL}$, et al. Stereotactic hypofractionated accurate radiotherapy of the prostate (SHARP), 335 Gy in five fractions for localized disease: first clinical trial results. Int J Radiat Oncol Biol Phys. 2007;67:1099-105.

23. Tang Cl, Loblaw DA, Cheung P, et al. Phase I/II study of a five-fraction hypofractionated accelerated radiotherapy treatment for low-risk localised prostate cancer: early results of pHART3. Clin Oncol (R Coll Radiol). 2008;20:729-37.

24. McBride SM, Wong DS, Dombrowski JJ, et al. Hypofractionated stereotactic body radiotherapy in low-risk prostate adenocarcinoma: preliminary results of a multi-institutional phase 1 feasibility trial. Cancer. 2012:118:3681-90.

25. Alongi F, Cozzi L, Arcangeli S, et al. Linac based SBRT for prostate cancer in 5 fractions with VMAT and flattening filter free beams: preliminary report of a phase II study. Radiat Oncol. 2013;8:171.

26. Boyer MJ, Papagikos MA, Kiteley R, et al. Toxicity and quality of life report of a phase II study of stereotactic body radiotherapy (SBRT) for low and intermediate risk prostate cancer. Radiat Oncol. 2017;12(1):14.

27. King CR, Brooks JD, Gill H, et al. Long term outcomes from a prospective trial of stereotactic body radiotherapy for low-risk prostate cancer. Int J Radiat Oncol Biol Phys. 2012:82:877-82.

28. Bolzicco G, et al. A single-center study of 100 consecutive patients with localized prostate cancer treated with stereotactic body radiotherapy. BMC Urol. 2013;13:49.

29. Elias E, Helou J, Zhang L, et al. Dosimetric and patient correlates of quality of life after prostate stereotactic ablative radiotherapy. Radiother Oncol. 2014;112:83-8.

30. Katz AJ, Kang J. Quality of life and toxicity after SBRT for organ confined prostate cancer, a 7-year study. Front Oncol. 2014;4:301.

31. Bernetich $M$, Oliai $C$, Lanciano $R$, et al. SBRT for the primary treatment of localized prostate cancer: the effect of Gleason score, dose and heterogeneity of intermediate risk on outcome utilizing 2.2014 NCCN risk stratification guidelines. Front Oncol. 2014;4:312

32. Gurka MK, Chen LN, Bhagat A, et al. Hematuria following stereotactic body radiation therapy (SBRT) for clinically localized prostate cancer. Radiat Oncol. 2015:19(10):44.

33. Seymour ZA, Chang AJ, Zhang L, et al. Dose-volume analysis and the temporal nature of toxicity with stereotactic body radiation therapy for prostate cancer. Pract Radiat Oncol. 2015;5:e465-72. 
34. Qi XS, Wang JP, Gomez CL, et al. Plan quality and dosimetric association of patient-reported rectal and urinary toxicities for prostate stereotactic body radiotherapy. Radiother Oncol. 2016;121:113-7.

35. Kole TP, Tong M, Wu B, et al. Late urinary toxicity modeling after stereotactic body radiotherapy (SBRT) in the definitive treatment of localized prostate cancer. Acta Oncol. 2016;55:52-8.

36. Helou J, D'Alimonte L, Quon H, et al. Stereotactic ablative radiotherapy in the treatment of low and intermediate risk prostate cancer: Is there an optimal dose? Radiother Oncol. 2017:123:478-82.

37. Zhang L, Johnson J, Gottschalk AR, et al. Receiver operating curves and dose-volume analysis of late toxicity with stereotactic body radiation therapy for prostate cancer. Pract Radiat Oncol. 2017;7:e109-16.

38. Jackson WC, Dess RT, Litzenberg DW, et al. A multi-institutional phase 2 trial of prostate stereotactic body radiation therapy (SBRT) using continuous real-time evaluation of prostate motion with patient reported quality of life. Pract Radiat Oncol. 2018;8:40-7.

39. Musunuru HB, Davidson M, Cheung P, et al. Predictive parameters of symptomatic hematochezia following 5-fraction gantry-based SABR in prostate cancer. Int J Radiat Oncol Biol Phys. 2016;94:1043-51.

40. Miszczyk L, Namysl Kaletka A, Napieralska A, et al. Cyberknife radioablation of prostate cancer: preliminary results for 400 patients. Asian Pac J Cancer Prev. 2017;18:1007-13.

41. Zelefsky MJ, Pinitpatcharalert A, Kollmeier M, et al. Early tolerance and tumor control outcomes with high-dose ultrahypofractionated radiation therapy for prostate cancer. Eur Urol Oncol. 2020;3(6):748-55.

42. King $C R$, et al. Stereotactic body radiotherapy forlocalized prostate cancer: pooled analysis from a multi-institutional consortium of prospective phase II trials. Radiother Oncol. 2013;109:217-21.

43. Sheets NC, Goldin GH, Meyer AM, et al. Intensity-modulated radiation therapy, proton therapy, or conformal radiation therapy and morbidity and disease control in localized prostate cancer. JAMA. 2012;307:1611-20.
44. Coen JJ, Bae K, Zietman AL, et al. Acute and late toxicity after dose escalation to $82 \mathrm{~Gy}$ E using conformal proton radiation for localized prostate cancer: initial report of American college of radiology Phase II study 03-12. Int J Radiat Oncol Biol Phys. 2011;81:1005-9.

45. Lukka H, Stephanie P, Bruner D, et al. Patient-reported outcomes in NRG oncology/RTOG 0938, a randomized phase 2 study evaluating 2 ultrahypofractionated regimens (UHRs) for prostate cancer. Int J Radiat Oncol Biol Phys. 2016;94:2.

46. Helou J, D'Alimonte L, Quon H, et al. Stereotactic ablative radiotherapy in the treatment of low and intermediate risk prostate cancer: Is there an optimal dose? Radiother Oncol. 2017.

47. Lovelock DM, Messineo AP, Cox BW, et al. Continuous monitoring and intrafraction target position correction during treatment improves target coverage for patients undergoing SBRT prostate therapy. Int J Radiat Oncol Biol Phys. 2015;91(3):588-94.

48. Cavanaugh SX, Fuller CD, Kupelian PA, et al. Time and PSA threshold model prognosticates long-term overall and disease-specific survival in prostate cancer patients as early as 3 months after external beam radiation therapy. Prostate Cancer Prostatic Dis. 2005;8(4):353-8.

49. Pinkawa M, Piroth MD, Holy $R$, et al. Prostate-specific antigen kinetics following external-beam radiotherapy and temporary (Ir-192) or permanent (I-125) brachytherapy for prostate cancer. Radiother Oncol. 2010;96(1):25-9.

50. Kubicek GJ, Naguib M, Redfield S, et al. PSA decrease during combinedmodality radiotherapy predicts for treatment outcome. Int J Radiat Oncol Biol Phys. 2010;78(3):759-62.

\section{Publisher's Note}

Springer Nature remains neutral with regard to jurisdictional claims in published maps and institutional affiliations.
Ready to submit your research? Choose BMC and benefit from:

- fast, convenient online submission

- thorough peer review by experienced researchers in your field

- rapid publication on acceptance

- support for research data, including large and complex data types

- gold Open Access which fosters wider collaboration and increased citations

- maximum visibility for your research: over $100 \mathrm{M}$ website views per year

At BMC, research is always in progress.

Learn more biomedcentral.com/submissions 